УДК 336.025

DOI https://doi.org/10.32837/pyuv.v1i3(28).343

\author{
С. Г. Науменко \\ старший викладач кафедри фінансового права \\ та фіскального адліністрування \\ Національної акаделії внутрішніх справ
}

Л. В. Герасименко кандидат юридичних наук, доцент, завідувач кафедри забезпечення фінансової безпеки та фінансового розслідування Національної акаделії внутрішніх справ

\title{
СУБ’СКТИ СИСТЕМИ ГАРАНТУВАННЯ ВКЛАДІВ ФІЗИЧНИХ ОСІБ В УКРАЇНІ
}

Сьогодення свідчить про те, що національна банківська система суттєво впливає на стан економічної ситуації в державі, що своєю чергою безпосередньо залежить від якості та структури ресурсів, які банки злучають, у тому числі й у вигляді тимчасово вільних коштів фізичних осіб. Проте в банківській системі України спостерігається динамічне поширення кризових явищ, при чому кожне наступне провокується появою попереднього. 3 огляду на це перед державою постає завдання створити належні умови для того, щоб клієнти, а також потенційні партнери усвідомлювали позитивний імідж банківських установ та відчували безпеку своїх вкладів. А це можливо лише за умови ефективного та злагодженого функціонування механізму залучення банками тимчасово вільних ресурсів, однією зі складових частин якого є система гарантування вкладів фізичних осіб.

Проблемні питання функціонування системи гарантування вкладів фізичних осіб в Україні у своїх працях досліджували С. Алексєєв, К. Алексійчук, Д. Бахрах, Я. Берназюк, А. Бобанич, В. Бобиль, Т. Бойчук, М. Брагинський, А. Бухтіарова, I. Бучко, Л. Воронова, Л. Василенко, Н. Галайко, С. Глуговська, Ж. Довгань, В. Копєйчиков, С. Козьменко, М. Кучерявенко, Т. Мазур, Д. Мейєр, І. Михайловська, Л. Недеря, А. Нечай, В. Огієнко, О. Орлюк, Ю. Пасічник, П. Пацурківський, 3. Руденко, С. Савченко, В. Саєнко, Ю. Самура, Ю. Серпінова, О. Скакун, Є. Ходак, О. Шебанов, І. Школьник тощо. Проте особливості суб'єктного складу системи гарантування вкладів фізичних осіб розглянуті недостатньо.

Метою статті є аналіз функціональних особливостей суб'єктів системи гарантування вкладів фізичних осіб,їх взаємодії та впливу наїі стабільність.

Система гарантування вкладів фізичних осіб за своєю функціональною спрямованістю має захищати права і законні інтереси вкладників банків, сприяти зміцненню довіри до банківської системи України, стимулювати залучення коштів у банківську систему України, забезпечувати ефектив- ну процедуру виведення неплатоспроможних банків з ринку та ліквідації банків.

Згідно з результатами аналізу сучасного правового регулювання системи гарантування вкладів фізичних осіб суб'єктів досліджуваної системи можна об'єднати у дві такі великі групи: суб'єкти пасивної участі та суб'єкти активної участі. До першої із запропонованих груп належать особи, чиї інтереси щодо повернення вкладів забезпечує держава в особі різноманітних уповноважених осіб, а також особи, які розмістили на своїх рахунках вклади за умови їх подальшого повернення. До другої - особи, що розробляють та запроваджують заходи гарантування вкладів фізичних осіб.

Найбільш численними представниками суб'єктів пасивної участі є вкладники, якими відповідно до пп. 4 п. 1 ст. 2 Закону України «Про систему гарантування вкладів фізичних осіб» $€$ фізичні особи (у тому числі фізичні особи-підприємці), які уклали або на користь яких було укладено договір банківського вкладу (депозиту), банківського рахунку, або які є власниками іменного депозитного сертифіката. При цьому фізична особа-підприємець має право на гарантування вкладів у випадку, якщо банк, у якому було розміщено депозит, було віднесено до категорії неплатоспроможних після 1 січня 2017 року.

До числа суб'єктів пасивної участі системи гарантування вкладів фізичних осіб доцільно віднести також членів кредитних спілок, які роблять внески на рахунки таких спілок, адже вклади на рахунки, відкриті в банках, та внески (вклади) членів кредитної спілки на її депозитні рахунки, відкриті у встановленому законом порядку, мають бути повернені вкладникам у визначений строк.

Отже, суб’єктами пасивної участі слід визнати тих осіб, чиї інтереси безпосередньо підлягають захисту та гарантуванню, тобто фізичних осіб.

Суб’єктами активної участі пропонуємо вважати тих суб'єктів, від чиєї діяльності безпосередньо залежить саме забезпечення належного функціонування системи гарантування вкладів фізичних 
осіб. Такими суб'єктами є Верховна Рада України, Фонд гарантування вкладів фізичних осіб (далі - ФГВФО), Кабінет Міністрів України, Національний банк України (далі - НБУ) та банківські установи.

На першій сходинці серед суб'єктів активної участі системи гарантування вкладів фізичних осіб перебувають банківські установи, які відповідно до чинного законодавства є учасниками ФГВФО з моменту одержання банківської ліцензії. Вони займають окрему нішу у системі гарантування вкладів фізичних осіб, адже банки забезпечують створення додаткової гарантії з боку системи гарантування залучених ресурсів, наявність доходу вкладника у формі відсотка, формування високоліквідної форми заощаджень грошових коштів, системи захисту заощаджень від знецінення внаслідок інфляційних процесів [1, с. 76]. Банки беруть безпосередню участь у формуванні обсягу коштів ФГВФО у двох таких формах: одноразово (при отриманні банківської ліцензії протягом 30 днів у розмірі $1 \%$ від свого статутного капіталу) та регулярно (щорічно у розмірі $0,5 \%$ від бази нарахування в національній валюті та 0,8\% від бази нарахування в іноземній валюті).

Серед банківських установ як учасників ФГВ$\Phi 0$ є виняток - Державний Ощадний банк України, який займає відокремлене місце у системі гарантування вкладів фізичних осіб. Проте це суперечить принципам IADI та нормам $€$, які вимагають участі усіх кредитних установ у системі страхування складів [2, с. 23]. Зокрема, основні принципи Міжнародної асоціації страховиків депозитів для ефективних систем страхування депозитів та Директива № 2014/49/ЄС Європейського Парламенту та Ради від 16 квітня 2014 року про схеми гарантування депозитів вимагають обов'язкового членства в системі страхування депозитів усіх банків, у тому числі й державних.

Нині обговорюється думка щодо доцільності включення до системи гарантування залучених ресурсів парабанківських фінансових установ [1, с. 77]. Відповідно до чинного законодавства не лише банки надають послуги із залучення тимчасово вільних коштів фізичних осіб. Згідно з п. 1 ст. 21 ЗУ «Про кредитні спілки» кредитна спілка залучає на договірних умовах внески (вклади) своїх членів на депозитні рахунки як у готівковій, так і в безготівковій формі. Ця послуга фактично є операцією із залучення фінансових активів для наступного їх повернення. Відповідно до абз. 5 п. 3 Ліцензійних умов провадження господарської діяльності з надання фінансових послуг (крім професійної діяльності на ринку цінних паперів) [3] вона є різновидом фінансової послуги, що передбачає залучення фінансовою установою фінансових активів на підставі письмового договору з особою (вкладником), яка не $\epsilon$ фінансовою установою, із зобов'язанням фінансової установи щодо наступного повернення таких коштів у визначений у договорі строк з виплатою вкладнику відсотків (винагороди). Здійснюється така діяльність виключно за наявності відповідної Ліцензії, виданої Національною комісією, що здійснюе державне регулювання у сфері ринків фінансових послуг. Тобто право надавати фінансову послугу щодо залучення фінансових активів із зобов'язанням щодо наступного їх повернення мають банки або кредитні спілки. Інші фінансові установи такого права не мають. Викладене вище безпосередньо свідчить про доцільність передбачити участь кредитних спілок у ФГВФО. Такий підхід повністю підтримує вимоги $€ \mathrm{C}$, закріплені у Директивах ЄС № 2014/59/ЄС та № 2014/49/СС Європейського Парламенту, щодо обов'язкової участі кредитних спілок у системі гарантування вкладів фізичних осіб.

ФГВФО як суб'єкт активної участі системи гарантування вкладів фізичних осіб посідає наступну сходинку аналізованої системи. Відповідно до чинного законодавства ФГВФО - це юридична особа, яка виконує спеціальні функції у сфері гарантування вкладів фізичних осіб, виведення неплатоспроможних банків з ринку і ліквідації банків. Фонд був створений у 1998 році в результаті підписання Указу Президента України «Про заходи щодо захисту прав фізичних осіб - вкладників комерційних банків» [4]. Діяльність Фонду у повному обсязі розпочалась у 2001 році з прийняття Закону України «Про Фонд гарантування вкладів фізичних осіб». Фонд набув статусу економічно самостійної установи із самостійним балансом, поточним та іншими рахунками в НБУ, а також рахунками в цінних паперах у депозитарних установах - державних банках.

Оскільки відповідно до ч. 1 ст. 4 ЗУ «Про систему гарантування вкладів фізичних осіб» основним завданням Фонду є забезпечення функціонування системи гарантування вкладів фізичних осіб та виведення неплатоспроможних банків з ринку, саме ФГВФО виконує провідну роль у гарантуванні вкладів фізичних осіб. Він гарантує кожному вкладникові банка - учасника системи гарантування вкладів - виплату недоступних депозитів у разі банкрутства даної банківської установи [5, с. 127]. Сьогодні гарантована сума становить 200 тис. грн. Зазначений розмір закріплений в ЗУ «Про систему гарантування вкладів фізичних осіб», хоча деякі автори наголошують на тому, що саме ФГВФО приймає рішення про підвищення розміру відшкодування, у чому він орієнтується на зміну середнього розміру вкладу та на визначення його величини на основі розміру ВВП на душу населення [5, с. 127]. Дійсно, ФГВФО розраховує бажані розміри відшкодування та готує відповідний законопроєкт, який подається 
на розгляд до Верховної Ради України, а остання приймає рішення щодо зміни розміру відшкодування за вкладами фізичних осіб.

Наступним органом в системі гарантування вкладів фізичних осіб є Національний банк України. Відповідно до ЗУ «Про систему гарантування вкладів фізичних осіб», ЗУ «Про Національний банк України» та Положення про підтримку ліквідності Національним банком України Фонду гарантування вкладів фізичних осіб [6] НБУ веде рахунки ФГВФО, ініціює участь представників в інспекційних перевірках проблемних банків шляхом їх включення до складу інспекційної групи, делегує та відкликає своїх представників (у кількості двох осіб) з адміністративної ради Фонду, отримує та аналізує річний звіт ФГВФО разом з аудиторським висновком щодо його діяльності, приймає рішення про віднесення банку до категорії проблемних, а також про визнання банку неплатоспроможним, про відкликання банківської ліцензії та ліквідацію банку, у тому числі за зверненням ФГВФО, надає ФГВФО кредити у національній валюті або відкриває йому кредитну лінію, затверджує план врегулювання, поданий ФГВФО, щодо виведення неплатоспроможного банку з ринку, застосовує право безспірного списання коштів з кореспондентського рахунку банку (крім тих, що віднесені до категорії неплатоспроможних, які виводяться ФГВФО з ринку) на користь ФГВФО у разі звернення Фонду, викупає у ФГВФО державні облігації України тощо.

Отже, НБУ фактично забезпечує фінансові можливості ФГВФО гарантувати повернення депозитів вкладникам банків, які визнані неплатоспроможними, щодо яких прийняте рішення про їх виведення з ринку. Тобто НБУ виконує забезпечувальну функцію щодо діяльності ФГВФО як одного з провідних суб’єктів системи гарантування вкладів фізичних осіб. Зокрема, у день створення Фонду НБУ зробив внесок у розмірі 20 мільйонів гривень.

Ще одним із суб’єктів досліджуваної системи, про який варто згадати, є Кабінет Міністрів України, який відповідно до чинного законодавства делегує та відкликає свого представника з адміністративної ради Фонду, отримує та аналізує річний звіт ФГВФО разом з аудиторським висновком щодо його діяльності, за наявності ризику недостатності коштів ФГВФО та за наявності відповідної заявки, що надійшла від Фонду, розробляє і подає до Верховної Ради України законопроєкт щодо надання ФГВФО додаткових коштів за рахунок Державного бюджету за умови відсутності у Законі «Про Державний бюджет України» на поточний рік бюджетних призначень у необхідному Фондові розмірі, надає ФГВФО кредити або безповоротну фінансову допомогу за рахунок коштів Державного бюджету України, розробляє та затверджує методику визначення обсягу ризику недостатності коштів ФГВФО, розробляє та затверджує порядок надання кредиту або внеску держави на безповоротній основі ФГВФО, має право брати участь у виведенні з ринку неплатоспроможного банку за наявності відповідного рішення.

Також свою нішу у системі гарантування вкладів фізичних осіб займає Верховна Рада України, яка у межах своїх повноважень делегує та відкликає свого представника 3 адміністративної ради Фонду, отримує та аналізує річний звіт ФГВФО разом з аудиторським висновком щодо його діяльності, розглядає законопроєкт, поданий Міністерством фінансів України щодо надання ФГВФО додаткових коштів за рахунок Державного бюджету за умови відсутності у Законі «Про Державний бюджет України» на поточний рік бюджетних призначень у необхідному Фондові розмірі, розглядає та приймає законопроєкти, які регулюють суспільні відносини у сфері гарантування вкладів фізичних осіб.

Також до системи гарантування вкладів фізичних осіб слід віднести Комітет Верховної Ради України з питань фінансової політики і банківської діяльності, який розробляє проєкти законів та інших актів Верховної Ради України щодо повернення заощаджень населенню, здійснює попередній розгляд та підготовку висновків і пропозицій щодо законопроєктів, які стосуються повернення заощаджень населенню, доопрацьовує за дорученням Верховної Ради України окремі законопроєкти, які регулюють суспільні відносини у сфері гарантування вкладів фізичних осіб, а також узагальнює зауваження і пропозиції, що надійшли до зазначених законопроєктів, проводить збір та аналіз інформації щодо стану повернення заощаджень населенню, організовує слухання $з$ цих питань, готує відповідні матеріали на розгляд Верховної Ради України, здійснює попередній розгляд і підготовку висновків і пропозицій щодо надання згоди на обов'язковість чи денонсацію міжнародних договорів України у сфері гарантування вкладів фізичних осіб тощо.

Наведена структура суб'єктів активної участі системи гарантування вкладів фізичних осіб була дещо розширена порівняно з переліком суб'єктів, визначених у п. 15 ст. 2 ЗУ «Про систему гарантування вкладів фізичних осіб». 3 огляду на це вважаємо за доцільне доповнити перелік суб'єктів системи гарантування вкладів фізичних осіб, наведений у п. 15 ст. 2 цього Закону, Верховною Радою України та викласти дефініцію системи гарантування вкладів фізичних осіб у такій редакції: «Система гарантування вкладів фізичних осіб - це сукупність відносин, що регулюються цим Законом, суб'єктами яких є ФГВФО, Верховна Рада України, Кабінет Міністрів України, НБУ, банки, кредитні спілки та вкладники». 


\section{Jimepamypa}

1. Мельник А.Т. Функціонування системи гарантування залучених ресурсів у контексті забезпечення стабільності фінансової системи України. Наукові записки Національного університету "Острозька академія». Серія «Економіка». 2013. Вип. 22. С. 75-78.

2. Даниленко А. Еволюція системи гарантування вкладів в Україні до світових стандартів: макропруденційний аспект. Вісник Національного банку України. 2017. № 242. C. $15-30$.

3. Ліцензійні умови провадження господарської діяльності з надання фінансових послуг (крім професійної діяльності на ринку цінних паперів) : Постанова Кабінету Міністрів України від 7 груд. 2016 р. № 913. URL: https://zakon.rada.gov.ua/laws/show/ 913-2016-\% D0\% BF.

4. Про заходи щодо захисту прав фізичних осіб вкладників комерційних банків : Указ Президента України від 10 верес. 1998 р. № 996/98. URL: https://zakon.rada.gov.ua/laws/show/996/98.

5. Заславська O.I. Тенденції розвитку гарантування вкладів фізичних осіб в Україні. Вісник Волин ського інституту еконоліки та менеджменту. 2016. Вип. 16. С. 121-129.

6. Про затвердження Положення про підтримку ліквідності Національним банком України Фонду гарантування вкладів фізичних осіб : Постанова Національного банку України від 18 бер. 2013 № 95. URL: https://zakon.rada.gov.ua/laws/show/z0543-13.

\section{Анотація}

Науменко С. Г., Герасименко Л. В. Суб'скти системи гарантування вкладів фізичних осіб в Україні. Стаття.

У статті розглянуто суб'єктний склад системи гарантування вкладів фізичних осіб. Суб'єктів системи гарантування вкладів фізичних осіб запропоновано об'єднати у дві такі великі групи: суб'єкти пасивної участі та суб'єкти активної участі. До першої з визначених груп віднесено осіб, чиї інтереси щодо повернення вкладів забезпечує держава (вкладники), а також осіб, які розмістили на своїх рахунках вклади за умови їх подальшого повернення (члени кредитних спілок). До другої групи належать особи, що розробляють та запроваджують заходи гарантування вкладів фізичних осіб (Верховна Рада України, Комітет Верховної Ради України з питань фінансової політики і банківської діяльності, Фонд гарантування вкладів фізичних осіб, Кабінет Міністрів України, Національний банк України та банківські установи). Проаналізовано роль кожного із суб'єктів активної участі системи гарантування вкладів фізичних осіб в ефективному та злагодженому функціонуванні механізму залучення банками тимчасово вільних ресурсів. Провідну роль визнано за банківськими установами, які є учасниками Фонду гарантування вкладів фізичних осіб з моменту одержання банківської ліцензії. Виняток становить Державний Ощадний банк України, який займає відокремлене місце у системі гарантування вкладів фізичних осіб. Визначено, що не менш важливу роль відіграє Фонд гарантування вкладів фізичних осіб, який гарантує кож- ному вкладникові банка - учасника системи гарантування вкладів - виплату недоступних депозитів у разі банкрутства даної банківської установи. Фінансові можливості Фонду гарантувати повернення депозитів вкладникам банків, які визнані неплатоспроможними, щодо яких прийняте рішення про їх виведення з ринку, фактично забезпечує Національний банк України. Верховна Рада України та Кабінет Міністрів України також відіграють певну роль у належному функціонуванні системи гарантування вкладів фізичних осіб.

Ключові слова: гарантування вкладів фізичних осіб, вкладник, член кредитної спілки, Фонд гарантування вкладів фізичних осіб, банківська система, депозит.

\section{Summary}

Naumenko S. G., Gerasimenko L. V. Subjects of the deposit guarantee scheme for individuals in Ukraine. Article.

The article deals with the subjective composition of the deposit guarantee scheme for individuals. The subjects of the Deposit Guarantee Scheme are proposed to be grouped into two large groups, namely, Passive Participation Entities and Active Participation Entities. The first of the identified groups includes persons whose interest in repaying deposits is provided by the state (depositors) and persons who placed deposits in their accounts subject to their further repayment (members of credit unions). The second is persons developing and implementing measures for guaranteeing deposits of individuals (Verkhovna Rada of Ukraine, Verkhovna Rada of Ukraine Committee on Financial Policy and Banking Activities, Deposit Guarantee Fund, Cabinet of Ministers of Ukraine, National Bank of Ukraine and banking institutions). The second is persons developing and implementing measures for guaranteeing deposits of individuals (Verkhovna Rada of Ukraine, Verkhovna Rada of Ukraine Committee on Financial Policy and Banking Activities, Deposit Guarantee Fund, Cabinet of Ministers of Ukraine, National Bank of Ukraine and banking institutions). The role of each of the subjects of active participation of the Deposit Guarantee System in the efficient and harmonized functioning of the mechanism of attracting temporarily free banks by banks is analyzed. The leading role is recognized by banking institutions that are members of the Deposit Guarantee Fund of individuals since obtaining a banking license. The exception is the State Savings Bank of Ukraine, which occupies a separate place in the deposit guarantee scheme for individuals. It is determined that the Deposit Guarantee Fund plays an equally important role, which guarantees to every depositor of a participating bank the payment of inaccessible deposits in the event of bankruptcy of a given banking institution. The Fund's financial capacity to guarantee the repayment of deposits to depositors of banks that are declared insolvent and for which a decision to withdraw them from the market is actually provided by the National Bank of Ukraine. The Verkhovna Rada of Ukraine and the Cabinet of Ministers of Ukraine also play a role in the proper functioning of the Deposit Guarantee Scheme.

Key words: deposit guarantee, investor, member of credit union, deposit guarantee fund, banking system, deposit. 